\title{
Shamanistic Features in the Old Testament
}

\author{
by ARVID S. KAPELRUD
}

The question whether there are shamanistic features in the O.T. will receive different answers according to the definitions of the term shamanism. I prefer here to adhere to the definition given by H. S. Nyberg in his book Irans forntida religioner 1 (The ancient religions of Iran), which in its turn is based on the works of Stadling, Nioradze and E. Reuterskiöld. ${ }^{2}$

"The shaman is a person", says Nyberg, "who is able, with the help of psychical disposition and methodical training, to put himself into a trance.Before the beginning of the trance he sets himself into ecstasy, through different means: music on the magic drum, combined with song, dance and sometimes certain narcotics. The shaman sits most often on a seat designed for him and has often a staff of helpers, who assist him in the performance". ${ }^{3}$

According to Nioradze the goal of shamanizing is to get a direct communication with the spirits in order to I. make the shaman able to answer certain questions which are of interest to him and those present, 2. have the shaman ask the help of the spirits or the fulfilment of promises, 3 . have him make the spirits obey by force. ${ }^{4}$

H. S. Nyberg is of the opinion that shamanistic features are present in the Iranian magi and in Sufian dervishes within Islam, the latter probably directly influenced by Mongolian shamanism.

The question to be asked, then, is whether it is possible to find sha-

1 Irans forntida religioner, Stockholm 1937, pp. $186 \mathrm{ff}$. (German translation 1938 ).

2 J. Stadling, Shamanismen $i$ Norra Asien (Populära etnologiska skrifter, no. 7), Stockholm rigra.

G. Nioradze, Der Schamanismus bei den sibirischen Völkern, Stuttgart 1925.

E. Reuterskiöld, De nordiska lapparnas religion (Populära etnologiska skrifter, no. 8), Stockholm 19 r2.

3 Op. cit., p. I 87 .

4 Nioradze, p. 90. 
manistic features in the West Semitic world where the O.T. took shape. The first phenomenon arousing one's interest are the nabi-guilds, which the Israelites took over from the Canaanites, and which are so clearly depicted in the Books of Samuel. Samuel himself was called a rō'xh, a seer (I Sam. IX: 9). Also, a seer could show shamanistic features, as demonstrated by the seer (hōzæh) Bileam, who was "falling down, but having his eyes uncovered", probably in trance, Num XXIV: $4 \& \mathrm{r} 6$.

More characteristic were, however, the nabis, who were active at Canaanite cult places, where they used to gather in flocks. They used different means to bring themselves into ecstasy: harp, tambourine, flute and lyre are mentioned in I Sam. X: 5 . When the spirit came upon them, they prophesied and it is even so expressed that they were "turned into another man" (I Sam. $\mathrm{X}: 6)$.

When the nabis were in this condition, "turned into another man" and filled with God's spirit, they spoke the oracles which the spirit gave them. When the king needed divine assistance to start a new task, e.g. a war, he used to call his nabis, as it is told in the O.T. about King Ahab in the gth century B.C., I Kings XXII. The nabis were ordered to get in contact with the divine world, and in addition a definite answer was expected from them, namely a "yes" to the plans of the king. King Ahab liked to have his band of nabis in this way, but he also wanted to hear the opinion of Micaiah, the son of Imlah, in spite of the fact that this prophet used to predict evil for the king, I Kings XXII. One may easily get the impression that the king (and the narrator) considered the nabis as men who were themselves masters of their oracles and who could accordingly turn them in the direction which was wanted. If that was so, the purpose of the work of the nabis was identical with that mentioned above, in connection with the definition of shamanism.

In the narrative about the prophet Elijah's struggle with the Baal prophets on Mount Carmel it is told that these nabis used to limp around the altar in a characteristic dance. "They cried aloud, and cut themselves after their custom with swords and lances, until the blood gushed out upon them", as the narrator tells, I Kings XVIII: 26-29. They here obviously used means that were intended to cause ecstasy. The purpose of the ecstasy was to get into contact with the divine world.

The nabis often wore a special garment which indicated their profession. 
Elijah used to wear a garment of haircloth, with a girdle of leather about his loins, II Kings I: 8, cf. Zech. XIII: 4. Also in this way they marked themselves out as a special guild, which was called upon on certain occasions and asked to get in contact with the divine world. They managed to do so through their ecstasy. The purpose was also to influence the events of the future. The assumption of the persons commissioning them, was that the oracles should be in favour of them, predicting a happy future. This happy future could be created by the nabis, through their oracles which were supposed to be actively powerful.

The nabi phenomenon in Israel was of Canaanite origin. It was never fully accepted by the most severe Yahweh-adherents. More characteristic of this latter group were the so-called "prophets of doom", like Amos, Hoseah, Isaiah, Micah, Jeremiah and Zephaniah. They certainly had some outer features common with the nabis, but their preaching, which will not be discussed here, was different.

The nabis occurred at a time in the history of Israel when Canaanite influence, cultural and religious, was dominating, at the end of the period of the so called Judges, in the IIth Century B.C. In spite of resistance the nabis were able to keep their position until the end of the Kingdom of Judah in $5^{8} 7$ B.C. (Cf. the Book of Jeremiah, chap. 28-29.) There can be little doubt that their role was greater than it is depicted in the narratives which were controlled by the official Yahweh circles in the Books of Samuel and Kings.

With the definition of shamanism by Nyberg, cited above, one may be allowed to say that the difference between a shaman and a nabi was small. Difficulties arise, however, because the nabis were only described by opponents and there are many details in their work which we do not know for certain.

This holds true also of two groups of persons mentioned in the O.T., mediums and wizards (according to the Revised Standard Version), I Sam. XXVIII: $3 \&$ 9, Hebrew: ha-'obōt wěha-yiddéōni. They are mentioned in the narrative of King Saul's visit to the medium woman at En-dor. It is expressly stated that King Saul had driven the mediums and the wizards out of the country, I Sam. XXVIII: 3. When Saul considered it necessary to take this step, it may indicate that these persons played a role in his time, that they were so many and so much used that Yahweh-adherents reacted against them. 
'o $\bar{b} b$ was used as a designation for the spirits of the dead, who could be conjured and brought into open day by the medium. In a law paragraph in Lev. XX: 27 the text actually says: "A man or a woman in whom there are 'ôb or $y i d d e^{\leftarrow} \bar{o} n \bar{\imath}$ shall be put to death". As can be seen in the text of I Sam. XXVIII: $3 \& 9$ the word ' $\bar{o} b$, plural 'obott, may be used about the medium, which may in its turn be a consequence of the point of view in Lev. XX: 27 .

The problem is simpler with the word yiddě $\bar{o} n \bar{\imath}$, where the connection with the root $y a d a^{\circ}$ is obvious. This verb means to know, to have insight, and the word yiddé $\bar{o} n \bar{\imath}$ thus means one who has insight, one who knows what is going to happen, a soothsayer. The word has a close parallel in Akkadian $m u d u$, derived also from the root "to know". It was used in Akkadian as characteristic of the "soothsayer spirit" (KAT 590 f.).

Let us now have a look at the narrative about King Saul and the woman medium, as it is told in I Sam. XXVIII. The narrative is part of ancient strata. The king had forbidden the mediums to call forth the spirits of the dead. In his last desperate period, when everything went wrong and the enemies were victorious, he tried in vain to get divine guidance. It was completely useless, through dreams, through the oracles urim and tummim and through prophets. He therefore asked his servants to seek out for him a woman who was a medium, "one who reigned over spirits", as the Hebrew designation says: 'ešæet ba'ălat-'ôb (I Sam. XXVIII: 7). The designation is sufficiently clear, but it has also been used as a foundation for further reflections, worth mentioning, e.g. by Sigmund Mowinckel. He is of the opinion that because the calling forth of spirits was forbidden, it was not exercised by men in Israel, as was usual in other countries in the Middle East. It had sunk down to female necromancy. 1 Mowinckel also points to another meaning of the nomen ' $\bar{o} b$, which in the Book of Job, XXXII: 19 , is used in the meaning bag of goatskin, used for storing of wine. This identity of words may be accidental, but Mowinckel, like Nöldeke, Zimmern and GeseniusBuhl, is of the opinion that here is no accidence. As the word is used in I Sam. XXVIII: 8 Mowinckel finds it probable that ' $\bar{b} b$ means the tool with which the spirits were called forth (cf. Deut. XVII: II). As 'o $b$ may mean

1 Det Gamle Testamente, oversatt av Michelet, Mowinckel (etc.), vol. II, Oslo I935, p. 225. 
bag of goatskin, Mowinckel proposes to translate "sorcery bag" (Norwegian: "gand-sekk"). In verse 7 , mentioned above, he prefers the translation: "a woman who masters the ghosts".

The prohibition which King Saul tried to enforce upon his subjects is in line with that which was later underlined in Deuteronomy (XVIII: $9 \mathrm{ff}$.). It is there forbidden to burn one's son, to practise divination, to be a soothsayer, an augur, a sorcerer, a charmer, a medium, a wizard, or a necromancer. The narrative in I Sam XXVIII indicates that such prohibitions were rigorously enforced in the reign of King Saul, but the king's own action shows how deeply rooted they were and how hard it was to have them abolished.

Accompanied by two men the king arrived disguised by night at En-dor. $\mathrm{He}$ addressed the woman rather brusquely and ordered her to bring up for him whomever he might name to her. He used a verb, qasam, which in his mouth may have had a contemptuous tinge. It means to "practise divination", especially by mechanical means (Ezekiel XXI: 26). The word is used in the O.T., about the work of foreign, "false" prophets, Is. III: 2, XLIV: 25 , Jer. XXVII: 9, XXIX: 8.

The means for this divination were also indicated by the king, it was to be practised $b \vec{a} \bar{o} b$, "by a spirit", and his intention was to get in contact with the man he wanted. The man whose advice he wanted, was the seer Samuel, the man who had once anointed him as king. This revealed to the woman that her visitor was the king himself, but he had already sworn to her that no punishment would be inflicted upon her. The narrative does not indicate what means the woman used to bring up the spirit of Samuel. She may, however, have been in a trance, or smoke or incense may have played a role. King Saul had to ask her: "What do you see?" This gives the impression that she alone saw the spirit of Samuel. She answered: "I see an æ̌lōhim coming up out of the earth". The word æ̌lōhim does not here mean a god (as it is usually translated), but a being which was not of a human character, but rather what we should prefer to call a spirit, a ghost. This spirit of Samuel answered the questions which King Saul in his distress put to him.

In his conversation with the woman King Saul uses the word ' $\bar{o} b$, which Mowinckel in this case translates as "means of divination" (Norwegian: "gjenferdsmaneren"). He suggests that the word here (in verse 8) indicates the tool which the woman used in order to get into contact with the spirit of 
the dead man. Mowinckel points to the fact mentioned above that ' $\bar{o} b$ may mean a bag of goatskin. The word may then also indicate a being or an object which gives a muffled whining or growling sound (cfr. Is. VIII: I9, XXIX: 4) Usually, Mowinckel says, the word is understood as meaning the spirits of the dead, ghosts, but some scholars have thought of a tool through which it was thought possible to bring up spirits from the earth. It may have been something like the "bullroarer" (Norwegian: svirretre or brummetre) in primitive peoples. It was a piece of wood which gave a strong whining or growling sound when it was swung on a string. It was used at cultic festivals and supposed to bring the diviners and sorcerers in contact with the spirits. ${ }^{1}$

We shall not here discuss the question of the original meaning of the substantive ' $\bar{a} b$ further. Usually the word is used in the O.T. with the meaning "spirit", indicating the pale withering dead ones in the realm of shadows, Sheol. The one obvious exception in the O.T. is Job XXXII: I9, where the word means bag of goatskin.

Compressed as is the narrative of the woman medium in En-dor, we are not told all the details we should have liked to know, e.g. what were the special qualifications of this woman and which were the tools and means she used. The narrator is silent about the question whether she was in trance or not. She was able to describe the appearance of the ghost to Saul: that it was an old man, dressed in a robe, she alone saw the dead one. This may be an indication that she was really in a trance.

The dramatic narrative in I Sam. XXVIII gives an indication of what happened when the spirits of the dead were conjured up in ancient Israel. We cannot come much closer, and that is not astonishing when we consider that the O.T. texts were handed down in circles which were hostile to the practice of diviners and sorcerers. The narrative discussed above indicates that such a practice existed and that it was not so easily abolished through official decrees.

There is no reason to doubt that shamanistic practice was found in Canaan in the time of King Saul. This practice went far back in time and was found in Canaan before the invasion of the Israelites. The cult of the dead, which the archaeological diggings in Ras Shamra in Syria have revealed, existed

1 Op. cit., vol. I, Oslo I929, p. 384 . 
also in Canaan. It was accepted by the Israelites, a fact which is underlined by the way in which the prohibition against all kinds of sorcery and soothsaying is repeated in the O.T., Lev. XIX: $3 \mathrm{I}, \mathrm{XX}: 6,27$, Deut. XVIII: II, I Sam. XXVIII: 3, Is. VIII: I9.

Interesting are some words found in Is. VIII: I9. They may have been spoken by the prophet himself, in the latter half of the 8th Century B.C. The prophet spoke ironically about the people who consulted 'óbot yiddě $\bar{o}$ ìm, mediums and wizards, the two categories discussed above. It is mentioned here that it was characteristic of them to "chirp and mutter". The sharp words of the prophet and his indication that the attitude of the people towards the sorcerers was typical, reveals the strong grasp that the shamanistic rites still had, in spite of prohibitions and encroachments by kings and other authorities. It could last only so long as the traditions were handed down to coming generations. The sorcerers must have a chance to teach young men and women their methods. This was probably possible until the fall of Jerusalem in 587 B.C. After that time the characteristic shamanistic features seem to have receded completely into the background. Instead new religious and magic features were coming in. 